\title{
The Application of STAD Cooperative Learning Using Picture as the Media to Improve Students' Learning Outcomes and Motivation in Learning Social Science
}

\author{
Sri Handayani ${ }^{1}$, Yunastiti Purwaningsih ${ }^{1}$, Wiedy Murtini ${ }^{1}$ \\ ${ }^{1}$ Universitas Sebelas Maret Surakarta \\ Ir. Sutami No. 36 A, Jebres, Surakarta, Central Java 57126, Indonesia
}

\begin{abstract}
This research aimed to describe the effect of the STAD type of cooperative learning model application on learning motivation and outcome of Social Science in the in the 9th graders of MTs Negeri Sragen. This study was a Classroom Action Research (CAR) conducted in three cycles. Each cycle consisted of four stages: (1) planning, (2) acting, (3) observing, and (4) reflecting. The subject of research was the 9th graders of MTs Negeri Sragen, consisting of 36 students. Techniques of collecting data used were observation, interview, test, documentation, and questionnaire. Data analysis was carried out using statistic descriptive data analysis with percentage technique. The result of research showed that the score of successfully passing for Social Science learning was $68.6 \%$ in prior action, $72.8 \%$ in cycle I, $80 \%$ in cycle II, and $84.8 \%$ in cycle III. The score of learning motivation was 70.3 in prior action, $75.6 \%$ in cycle I, $79.6 \%$ in cycle II, and $88.4 \%$ in cycle III. The conclusion of research was that STAD type of cooperative learning model with pictorial media could improve learning outcome and learning motivation of Social Science subject.
\end{abstract}

Keywords: learning model; STAD type of cooperative learning model; motivation; learning outcome; Social Science

\section{INTRODUCTION}

Education is one of very important components in creating human resource (HR) in dealing with the time progress. The rapidly developing time will willy-nilly require a high-quality generation. High-quality human being is the competitive one in positive sense, by creating critical mindset, and well-established, creative and innovative reasoning. Education is considered as a means of improving an individual's ability and skill. Education is also considered as a means of improving quality, dignity and prestige. In the attempt of implementing national education, the attempts of conceiving and experiencing religious values, self-control, personality, intellectuality, noble character, and skill necessary to the self, society, nation, and state should be expanded, improved and utilized thereby becoming habituation in all classes of society.

Social Science is a lesson composed of a variety of social studies organized through education and psychological approaches and feasibility and meaningfulness to students and their life. Social Science (particularly, economics, history, geography, 
sociology and anthropology) contributes the concepts of science converted into knowledge related to social life that should be studied by students. Thus, social science plays a very important part in inculcating values, norms, and rules prevailing within society, so that an individual can perform his/her role as a good and responsible member of society. More broadly, social science builds the students into members of society and citizens who are responsible for mutual wellbeing as Social Science learning not only teaches the ways of socializing with community but also with natural environment. The students should have not only high knowledge and thinking ability but also high awareness and responsibility for society, nation, and state wellbeing. An objective of Social Science subject is to equip the students with basic competency of thinking logically and critically, curiosity, inquiry, problem solving and social life skills and communication, cooperation, and competition abilities in multicultural community at local, national, and global levels.

The result of observation on social science learning shows that students tend to be passive while teachers active. The learning outcome the students obtained are still below the minimum passing criterion (KKM). From the result of daily quiz for the $9^{\text {th }}$ grade, it can be seen that the comprehension of Social Science material is still low. It can be seen from the mean score of quiz in the odd semester of 2016/2017 school year (63), while the minimum passing criterion (KKM) is 75. It is because Social Science learning in MTs Negeri Sragen, particularly in the $9^{\text {th }}$ grade, is still conventional (Teacher Centered Learning) in which the students only sit down, listen to, and receive information. The information receiving method will be less effective because the memory strengthening process is only note making, so that the students are not accustomed to think or to find idea critically.

The result of observation on teaching-learning activity in the $9^{\text {th }}$ grade reveals that in Social Science learning the students receive the learning less enthusiastically, so that there is no spirit and motivation. The students tend to be bored and express their saturation in the following ways: 1) completing Social Science lesson assignment in less disciplined manner, 2) sometimes mistreating their friends, 3) talking to seatmate, or putting their head on the table, hitting the table while singing and musing, 4) incapable of completing the evaluation assignment timely, 5) often asking permission to go to toilet, 6) paying less attention to the teacher's explanation, and 7) sometimes playing truant at certain hours with many reasons. It makes the students get score below the minimum passing criteria in the final evaluation of Social Science subject.

The students' low learning outcome in Social Science is due to many factors, including internal and external ones. Internal factor includes less effective learning strategy, less concentration, less motivation or spirit to attend the learning, while external one includes less supporting school facility, preferring the teachers' teaching method inadequately, environment effect, disharmonious family condition, less supporting economic condition and etc. in addition, the number of learning groups per class in the $9^{\text {th }}$ grade is $36-38$ students with a very heterogeneous condition of student. Such the condition impacts on the less maximal and less effective class management.

To deal with the problem above, a teacher's creativity is needed to select and to apply an appropriate learning model corresponding to the learning target to be achieved. The use of appropriate learning model leads to an active, innovative, and creative learning process with high effectiveness. One of joyful learning models is the cooperative one. Isjoni (2013: 12) states that cooperative learning can improve the 
students' learning and their mutual help attitude in social behavior. Isjoni (2013: 12) suggests that cooperative learning is more appropriate to use in Social Science learning.

Suryani and Agung (2012: 80) state that cooperative learning is the learning approach focusing on the use of the small group of students to cooperate in maximizing the learning condition to achieve the objective. In addition, the use of small group encourages and to motivate the students to learn Social Science. Learning using cooperative model can be done to motivate the students to express their opinion bravely, to appreciate others' opinion, and to share ideas (Isjoni, 2013: 13). Additionally, in learning the students usually face exercises and problem solving.

Therefore, cooperative learning is very good to implement because the students can cooperate and help each other in dealing with the assignment encountered. In cooperative learning, the students are required to be active in the learning process thereby exerting positive effect on the quality of interaction and communication in learning and motivating the students to improve their learning achievement (Isjoni, 2013:13).

Student Team Achievement Division (STAD) is one type of cooperative learning in which the small groups of cooperating students are used in maximizing the learning condition in order to achieve the learning objective and to get maximal learning experience, either individually or in group.

The improvement of motivation and learning outcome can be achieved effectively when teachers also use adequate and varying learning media. The intended learning media is the one facilitating the students to understand the material studied, and used joyfully, thereby resulting in fun learning nuance. It is in line with Hamdani (2011: 244) state that learning media in teaching-learning process can generate new wish and interest, motivation and stimulation of learning activity, and even can affect the students psychologically. Learning media can be said as an instrument that can stimulate the learning process to occur within the students. Meanwhile, Anitah (2012: 5) defines media as everything used to distribute information. Media serve as a means of delivering information from the sender to the receiver of information. Moreover, when the media are varying, the learning circumstance will be more alive, joyful and meaningful.

Departing from the elaboration above, the research entitled "the STAD type of cooperative learning model application with pictorial media to improve learning motivation and outcome of Social Science subject in the $9^{\text {th }}$ graders of MTs Negeri Sragen" is considered to be necessary to do through Classroom Action Research (CAR). The objective of research is to improve learning outcome and learning motivation of Social Science in the $9^{\text {th }} 1$ graders of MTs N 1 Sragen. The indicator of research success is that learning outcome and learning motivation classically reach $80 \%$.

\section{METHOD}

This study was a Classroom Action Research (CAR). This research was Classroom Action Research. This research was conducted in three cycles. Every cycle consists of planning, acting, observing, and reflecting. This procedure of classroom action research is illustrated in Figure 1 below 


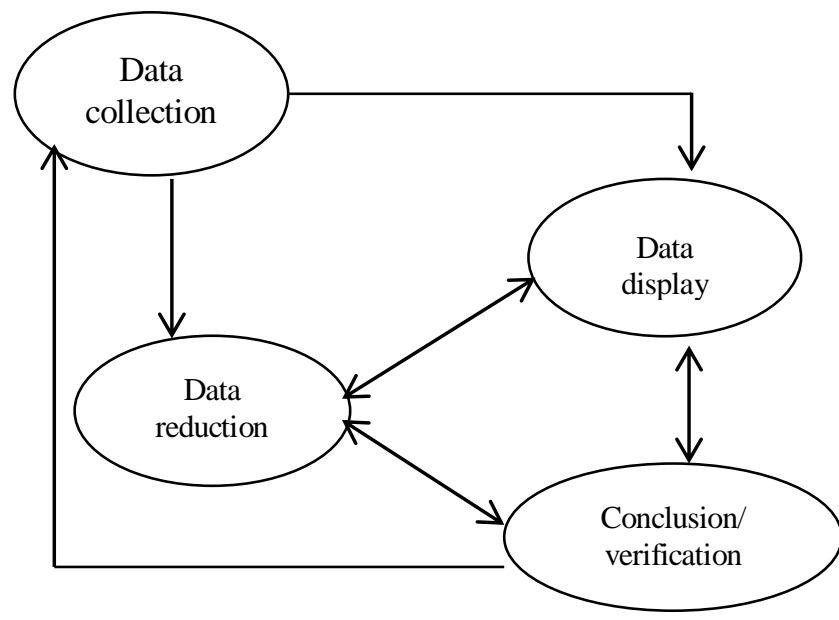

Figure 1. Research Procedure

The subject of research was the $9^{\text {th }} 1$ graders of MTs N Sragen in the school year of 2016/2017, consisting of 36 students: 22 girls and 14 boys. Techniques of collecting data used were observation, interview, test, questionnaire and documentation. Techniques of analyzing data used were qualitative and quantitative data analyses.

Qualitative data analysis was the one used to analyze the data obtained from the result of observation, interview and documentation. The qualitative data analysis is depicted in Figure 2 below.

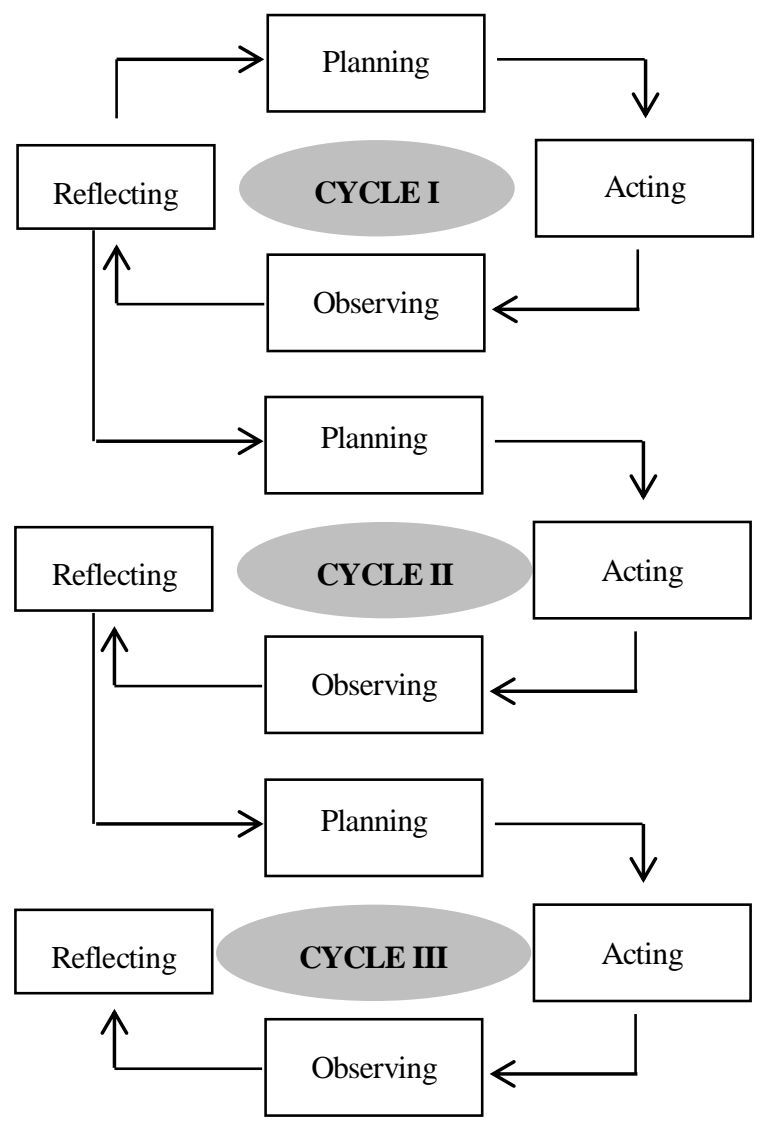

Figure 2. Qualitative Data Analysis Source: Sugiyono (2015: 331) 


\section{RESULT}

\section{Prior Action}

Meanwhile, quantitative data analysis is the one used to analyze the data obtained from test and learning motivation results. The quantitative data analysis was conducted using statistic descriptive method with percentage technique.

Before the Classroom Action Research (CAR) was conducted, the author conducted observation and test first. Observation activity was intended to find out the Social Science learning process in MTs N 1 Sragen. Meanwhile, test was intended to find out the students' ability in Social Science subject. In addition, test was also intended to find out the learning motivation in the $9^{\text {th }} 1$ MTs $N 1$ Sragen. Learning motivation was measured using questionnaire.

Learning outcome and learning motivation of students in prior action are presented in Table 1 below.

TABLE 1. LEARNING OUTCOME AND MOTIVATION IN PRIOR ACTION

\begin{tabular}{lc}
\hline Aspect & Percentage \\
\hline Learning Outcome & $68.6 \%$ \\
Learning Motivation & $70.3 \%$ \\
\hline
\end{tabular}

From the table above, it can be seen that the students' learning outcome in prior action is $68.6 \%$. It has not met the Minimum Passing Criterion (KKM). The Minimum Passing Criterion (KKM) in MTs N 1 Sragen for Social Science subject is 75. Classically, the learning outcome of students has not satisfied the expectation yet as it has not reached $80 \%$.

The table shows that learning motivation in prior action is $70.3 \%$. Learning motivation of students is still low because the learning motivation obtained based on the questionnaire distributed to the students has not reached $80 \%$, classically. Learning outcome and learning motivation run linearly in which the low learning outcome is due to the low learning motivation. For that reason, some action should be administered aiming to improve learning outcome and learning motivation. The action considered as capable of solving the problems in the $9^{\text {th }} 1$ MTs $N 1$ Sragen is cooperative learning model with pictorial media.

\section{Cycle I}

In cycle I, the author conducted planning, action, observation and reflection. The observation conducted in cycle I is based on the result of reflection on prior action research. The result of prior action shows the low learning outcome and learning motivation encouraging the author to conduct a Classroom Action Research (CAR). The planning in cycle I includes: developing learning design, developing pictorial media, developing test, and developing learning motivation questionnaire. Acting is the implementation stage in the learning in the classroom. The classroom learning is conducted according to the learning design developed. Thereafter, the students were tested and told to fill in the learning motivation questionnaire. Reflection is an activity of evaluating the result of Implementation. The aspects evaluated are learning outcome and learning motivation in cycle I.

Learning outcome and learning motivation in cycle I are shown in table 2 below. 
TABLE 2. LEARNING OUTCOME AND MOTIVATION IN CYCLE I

\begin{tabular}{lc}
\hline Aspect & Percentage \\
\hline Learning outcome & $72.8 \%$ \\
Learning motivation & $75.6 \%$ \\
\hline
\end{tabular}

The classical passing criteria of learning outcome in cycle I is $72.8 \%$, while that of learning motivation is $75.6 \%$. Learning outcome increases by $4.2 \%$ in cycle I. In fact, the increase in learning outcome is proportional directly to that in learning motivation. Learning motivation increases by $5.3 \%$ in cycle I. Figure 3 shows the comparative result of condition in prior action and cycle I.

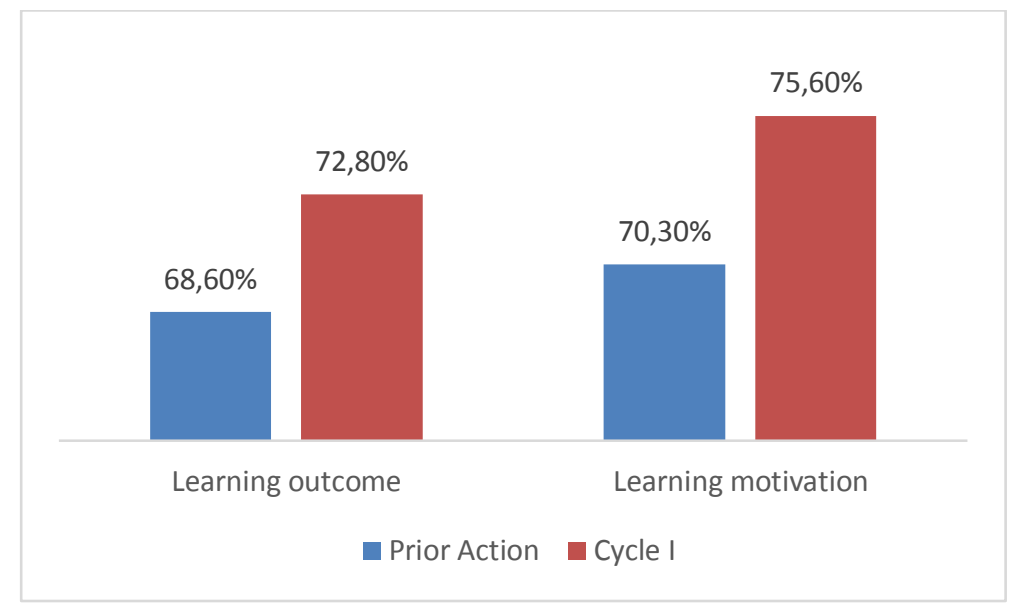

Figure 3. Comparison of prior action and cycle I

The comparison of condition in prior action and cycle I as shown in Figure 3 represents that the action administered in cycle $\mathrm{I}$ is successful, because there is an increase in learning outcome and learning motivation from prior action to cycle I. However, this success has not satisfied the expected indicator yet, so that the action should be followed with cycle II.

\section{Cycle II}

In cycle II, the author conducted planning, action, observation, and reflection. The observation conducted in cycle II is based on the result of reflection on cycle I. The result of cycle I shows that learning outcome and learning motivation has not satisfied yet the expected indicator. The planning in cycle II includes: developing learning design, developing pictorial media and developing test. Acting is the learning implementation stage in the classroom. The learning in the classroom is conducted according to the learning design prepared in cycle II. Thereafter, the students were tested and told to fill in the learning motivation questionnaire. Reflection is an activity of evaluating the result of Implementation. The aspects evaluated are learning outcome and learning motivation in cycle II. below.

Learning outcome and learning motivation in cycle I are shown in table 2

TABLE 3. LEARNING OUTCOME AND MOTIVATION IN CYCLE II

\begin{tabular}{lc}
\hline Aspect & Percentage \\
\hline Learning Outcome & $80 \%$ \\
Learning Motivation & $79.6 \%$ \\
\hline
\end{tabular}


The classical passing criteria of learning outcome in cycle II is $80 \%$, while that of learning motivation is $79.6 \%$. Learning outcome increased by $7.2 \%$ in cycle II. In fact, the increase in learning outcome is proportional directly to that in learning motivation. Learning motivation increases by $4 \%$ in cycle II.

This successfulness in cycle II results from the teacher who has been familiar with cooperative learning model. Meanwhile, the students feel more comfortable with group learning in cycle II. The students can cooperate well with their fellow members of group and can help each other. Figure 4 shows the result of comparison between cycle I and cycle II.

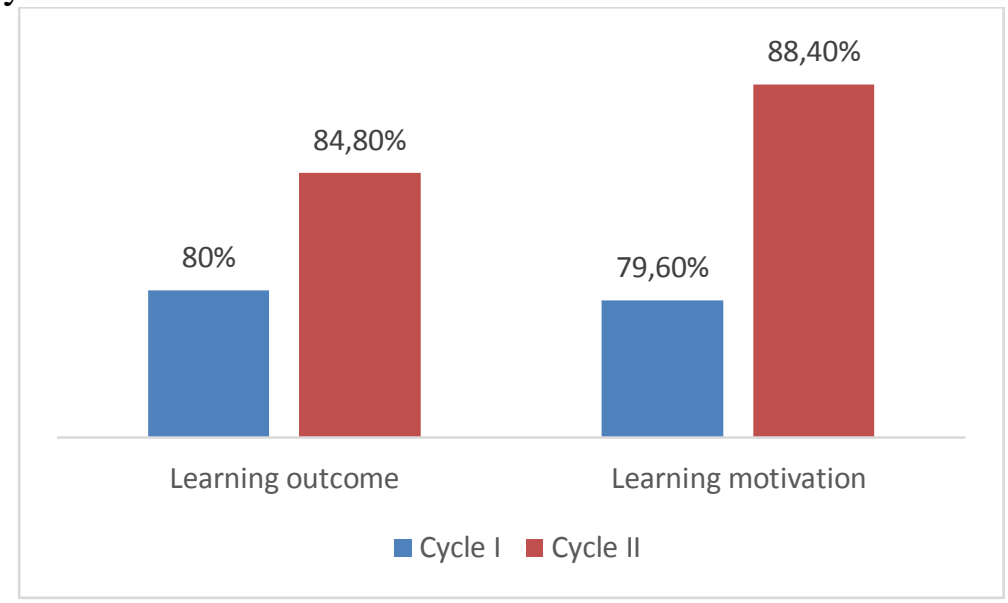

Figure 4. The Comparison of Cycle I And Cycle Ii

The comparison of cycle I and cycle II in Figure 4 indicates that the action given in cycle II is successful, because there is an increase in learning outcome and learning motivation from cycle I to cycle II. However, this success has not satisfied the expected indicator yet, so that the action should be followed with cycle III.

\section{Cycle III}

In cycle III, the author conducted the procedure as same as that in previous cycle: planning, action, observation, and reflection. The observation conducted in cycle III is based on the result of reflection on cycle II. The result of cycle II shows that learning outcome and learning motivation has not satisfied yet the expected indicator. The planning in cycle III includes: developing learning design, developing pictorial media and developing test. Acting is the learning implementation stage in the classroom. The learning in the classroom is conducted according to the learning design prepared in cycle III. Thereafter, the students were tested and told to fill in the learning motivation questionnaire. Reflection is an activity of evaluating the result of implementation. The aspects evaluated are learning outcome and learning motivation in cycle III. Learning outcome and learning motivation in cycle I are shown in Table 2 below.

\begin{tabular}{|c|c|}
\hline Aspect & Percentage \\
\hline Learning Outcome & $84.8 \%$ \\
\hline Learning Motivation & $88.4 \%$ \\
\hline
\end{tabular}

The classical passing criteria of learning outcome in cycle III is $84.8 \%$, while that of learning motivation is $88.4 \%$. Learning outcome increased by $4.8 \%$ in cycle III. In fact, 
the increase in learning outcome is proportional directly to that in learning motivation. Learning motivation increases by $8.8 \%$ in cycle III. Figure 4 shows the comparative result of cycle II and cycle III.

The comparison of cycle II and cycle III in Figure 4 indicates that the action given in cycle III is successful, because there is an increase in learning outcome and learning motivation from cycle II to cycle III. This success has satisfied the expected indicator, in both learning outcome and learning motivation. The data obtained in cycle III tends to be consistent with that in cycle II.

\section{DISCUSSION}

Cooperative learning model with pictorial media can improve the learning outcome effectively. It can be seen from the result of test ever increasing in each cycle. The learning outcome obtained increases consistently from prior cycle to cycle III. Figure 5 below is the summary of learning outcome obtained from prior action to cycle III.

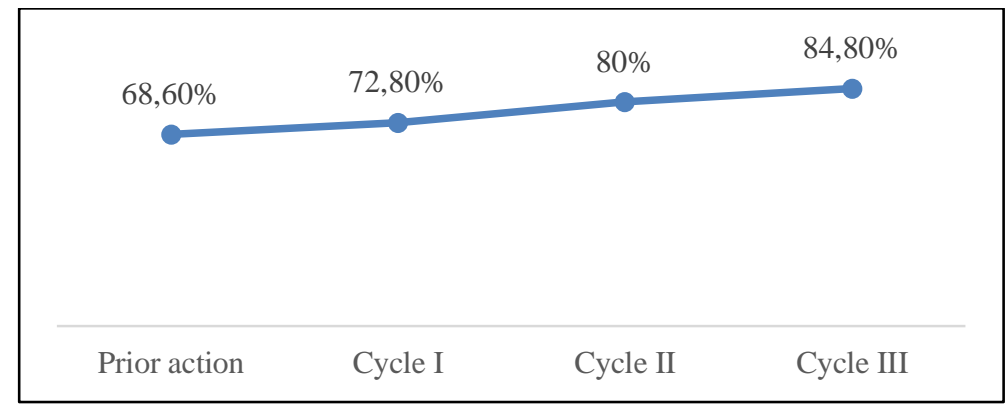

Figure 5. Learning outcome from prior action to cycle III

Learning outcome in Figure 5 indicates clearly that the chart increases over times. This result is in line with the result of research conducted by Van Wyk (2012), Wiguna et al (2013), and Sudrajat (2012) finding that cooperative learning model can improve learning outcome.

In addition to using STAD type of cooperative learning model, the improvement of learning outcome occurs due to the learning media use in learning. Learning media can motivate the students' learning effectively because learning media can help the students clarify information the teacher delivers.

The effectiveness of learning media use is in line with Meitepul (2011) study finding that pictorial media can improve the learning outcome.

In addition to improving the learning outcome, the STAD type of cooperative learning model application with pictorial media can improve the learning motivation of students in Social Science subject.

The learning motivation of students increases continuously from prior action to cycle III. 


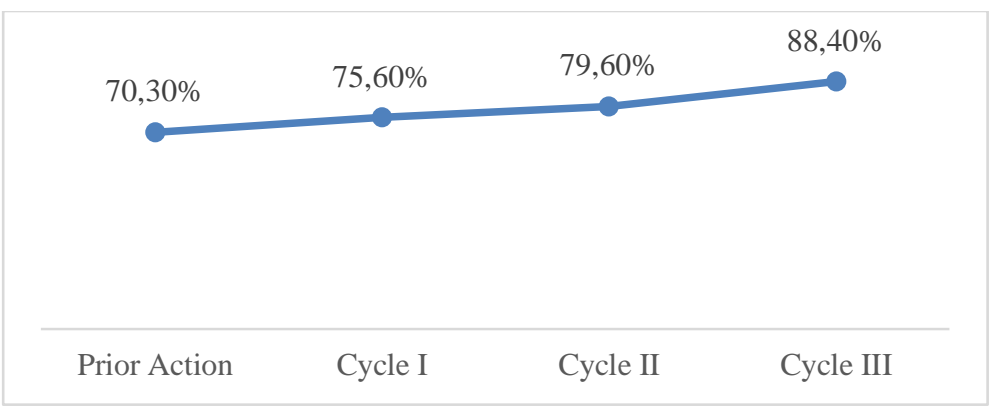

Figure 6. Result of learning motivation from prior action to cycle III

Figure 6 shows that the chart of learning motivation increases over times. Learning motivation measured in this research includes: responsibility, independency, persistence in dealing with assignment, motivation to be successful, preference to challenge, and consistency in working.

Learning outcome is proportional directly to learning motivation because the result of research shows that the better the learning motivation, the better is the learning outcome. Thus, it can be concluded that the STAD type of cooperative learning model application with pictorial media can improve learning outcome and learning motivation of Social Sciences subject in the $9^{\text {th }}$ graders of MTs Negeri Sragen.

\section{CONCLUSION}

Considering the result of research and discussion, the following conclusions could be drawn:

1. The STAD type of cooperative learning model application with pictorial media can improve the learning outcome of Social Science in the $9^{\text {th }}$ graders of MTs Negeri Sragen.

2. The STAD type of cooperative learning model application with pictorial media can improve the learning motivation of Social Science in the $9^{\text {th }}$ graders of MTs Negeri Sragen.

\section{REFERENCES}

[1] Anitah, Sri. (2012). Media Pembelajaran. Surakarta: Yuma Pustaka.

[2] Hamdani (2011). Strategi Belajar Mengajar. Bandung Pustaka Setia.

[3] Isjoni. (2014). Cooperative Learning: Efektifitas Pembelajaran Kelompok. Bandung: Alfabeta.

[4] Meitepul, E. (2011). Pembelajaran Membaca Teks Naratif dengan Menggunakan Media Gambar sebagai Alternatif Meningkatkan Hasil Belajar Siswa. Jurnal. Upi.Edu, 11(2) Oktober 2011.

[5] Suryani, Nunuk \& Agung, L. (2012). Strategi Belajar Mengajar. Yogyakarta: Ombak.

[6] Sudrajat, E. (2012). Upaya Peningkatan Aktivitas dan Hasil Belajar Siswa pada Mata Pelajaran Seni Budaya tentang Batik Celup melalui Metode Cooperative Learning Student Team Achievement Division (STAD) di Kelas VIII H SMPN 1 Pageragung Tahun 2011/2012. Jurnal Upi, Vol III, (1).

[7] Sugiyono (2015). Metode Penelitian Tindakan Komprehensif. Bandung: Alfabeta. 
[8] Van Wyk, M. (2012). The Effects of the STAD-Cooperative Learning Method on Student Achievement, Attitude and Motivation in Economic Education. J. Soc.Sci.33 (21), 261-270.

[9] Wiguna, S., Adnyawati., \& Wahyuni, S.D. (2013). Penerapan Model Pembelajarann Kooperatif Tipe STAD (Student Teams Achievement Divisions) Berbantuan LKS untuk Meningkatkan Motivasi dan Hasil Belajar Teknologi Informasi dan Komunikasi (TIK) Siswa di SMA Negeri 1 Kubutambahan (versi elektronik). Kumpulan Artikel Mahasiswa Pendidikan Teknik Informatika, 2 (6), 926-932. 